\title{
ANALISIS KINERJA PEMERINTAH DESA DALAM PEMBANGUNAN MASYARAKAT DI DESA BONTOMANAI KECAMATAN MANGARABOMBANG KABUPATEN TAKALAR
}

\author{
Sofyanto Torau \\ Fakultas Ilmu Sosial dan Ilmu Politik Universitas Indonesia Timur \\ Email : sofyanto.torau@uit.ac.id
}

\begin{abstract}
The village government is very instrumental in every activity in the administration of the village and must be able to carry out their duties in carrying out community development, development and empowerment of rural communities. In line with this, the aim of this study is to find out the performance of the village government in the context of implementing village community development in Bontomanai village, Mangarabombang District, Takalar Regency. The research approach used is qualitative which provides an overview of the problem under study and presents data and analyzes it. Data collection techniques through interviews and observation and documentation. The results showed that the performance of the village government in the context of village community development was quite good, with several indicators proposed by Bernardin and Russel namely work quantity, work quality, work knowledge, cooperation, creativity and personal quality of the village government in the implementation of development so that it still needed to be improved. The indicators that have not yet been achieved are the work knowledge and creativity of the village government which are still lacking in the implementation of development.
\end{abstract}

Keyword: Performance, village government, village community development

\begin{abstract}
ABSTRAK
Pemerintah desa sangat berperan dalam setiap kegiatan penyelenggaraan pemerintahan di desanya serta harus mampu menjalankan tugasnya dalam melaksanakan pemerintahannya, pembinaan masyarakat, pembangunan serta pemberdayaan masyarakat desa. Sejalan dengan hal ini, maka penelitian ini bertujuan untuk mengetahui kinerja pemerintah desa dalam rangka pelaksanaan pembangunan masyarakat desa di desa Bontomanai Kecamatan Mangarabombang Kabupaten Takalar. Pendekatan penelitian yang digunakan adalah kualitatif yang memberikan gambaran mengenai permasalahan yang diteliti serta menyajikan data dan menganalisisnya. Teknik pengumpulan data melalui wawancara serta observasi dan dokumentasi. Hasil penelitian menunjukkan bahwa kinerja pemerintah desa dalam rangka pembangunan masyarakat desa sudah cukup baik, dengan beberapa indikator yang dikemukakan oleh Bernardin dan Russel yakni kuantitas kerja, kualitas kerja, pengetahuan kerja, kerjasama, kreativitas dan kualitias pribadi pemerintah desa dalam pelaksanaan pembangunan sehingga masih perlu ditingkatkan. Adapun indikator yang belum tercapai adalah pengetahuan kerja dan kreativitas pemerintah desa yang masih kurang dalam pelaksanaan pembangunan.
\end{abstract}

Kata Kunci: Kinerja, Pemerintah Desa, Pembangunan Masyarakat Desa

\section{PENDAHULUAN}

Pembangunan masyarakat merupakan fenomena yang muncul sepanjang manusia hidup bermasyarakat dan keinginan manusia untuk memperoleh pemahaman tentang pembangunan masyarakat tersebut dilakukan melalui kajian pembangunan masyarakat. Dalam kajian tentang pembangunan 
masyarakat ini dikenal pula berbagai perspektif. Fenomena pembangunan masyarakat selama ini utamanya di negaranegara sedang berkembang dapat dilihat adanya perspektif yang dominan pada era tertentu. Perspektif tersebut pada eranya telah mewarnai kebijakan dan pelaksanaan pembangunan masyarakat negara-negara yang sedang berkembang.

Pembangunan saat ini lebih dipusatkan pada manusia. Model pembangunan yang berpusat pada manusia (people centered) serta terpenuhinya kebutuhan dasar masyarakat, tetapi yang lebih penting lagi adalah pada upaya meningkatkan kualitas manusia agar dapat meningkatkan partisipasi secara nyata dalam berbagai aktifitas kehidupan untuk mendorong terciptanya kegiatan produktif yang bernilai tinggi.

Pembangunan merupakan sebuah proses pengembangan kapasitas masyarakat dalam jangka panjang sehingga memerlukan perencanaan yang tepat dan akurat. Perencanaan ini berarti harus mampu mencakup kapan, di mana dan bagaimana pembangunan harus dilakukan agar mampu merangsang pertumbuhan ekonomi dan sosial secara berkesinambungan (Nurdin, n.d.). Untuk itu diperlukan kinerja yang baik bagi pemerintah dalam mengelola segala sumber daya yang ada agar pembangunan dapat berhasil dan tepat sasaran.

Pembangunan desa adalah pembangunan manusia seutuhnya dan seluruh masyarakat Indonesia. Pembangunan desa bersifat multisektoral karena menyangkut semua kehidupan masyarakat, sehingga pembangunan desa tidaklah merupakan pembangunan yang berdiri sendiri tetapi merupakan suatu kesatuan dengan pembangunan nasional di daerah. Sifat multisektoral yang melekat pada pembangunan desa mengharuskan pembangunan desa harus dilaksanakan secara terintegrasi dan terpadu, terpadu dalam perencanaan, pelaksanaan tersebut dicapai, berdaya guna dan berhasil guna (Soewignjo, 1986)
Adapun pemerintahan desa diselenggarakan oleh pemerintah desa (pasal 23). Pemerintah Desa sebagaimana dimaksud dalam pasal 23 adalah Kepala Desa atau yang disebut dengan nama lain yang dibantu oleh Perangkat Desa atau yang disebut dengan nama lain (pasal 25) Undang-undang Nomor 6 Tahun 2014 Tentang Desa. Sejalan dengan hal ini, Pemerintah Desa tentu sangat berperan dalam setiap kegiatan penyelenggaraan pemerintahan di desa, dalam hal ini adalah Kepala Desa. Kepala Desa sebagai Kepala Pemerintahan desa harus mampu menjalankan tugas pokoknya yang tertuang dalam pasal 26 Undang-undang Nomor 6 Tahun 2014 tentang Desa, yakni Kepala Desa bertugas menyelenggarakan Pemerintahan desa, melaksanakan pembangunan Desa, pembinaan kemasyarakatan desa dan pemberdayaan masyarakat desa.

Pembangunan sebagai gerakan, dimana harus dilaksanakan secara menyeluruh di pedesaan. Sebagai gerakan maka diperlukan kemampuan untuk menggerakkan masyarakat dalam melaksanakan pembangunan yang dilandasi oleh kesadaran untuk meningkatkan dirinya dalam keadaan yang lebih baik (Soewignjo, 1986). Dalam hubungan ini maka peranan kepemimpinan sangat menonjol. Dalam berbagai penelitian, keberhasilan daripada pembangunan desa tampak besar sekali. Hal ini disebabkan oleh kepemimpinan yang tepat adalah yang sesuai dengan kondisi masyarakat yang bersangkutan. Sehingga keberhasilan pembangunan di desa sangat ditentukan oleh pemimpinnya dalam hal ini adalah kepala desa.

Berdasarkan gambaran tersebut, menunjukkan bahwa keberhasilan dan kegagalan suatu program pembangunan sangat ditentukan oleh pemerintah desa terkait kinerjanya, terutama kepala desa sebagai pemimpin dalam penyelenggaraan urusan pemerintahan desa yang merencanakan, mengatur serta melaksanakan kegiatan pembangunan. 
Penelitian yang dilakukan oleh Maya Oribala dkk (2017) menunjukkan bahwa keberhasilan atau kegagalan program pembangunan desa sangat ditentukan oleh tingkat keteladanan kepala desa terkait kinerjanya, yakni dalam hal merencanakan, menggerakkan, memotivasi, mengarahkan, komunikasi, pengorganisasian dan pelaksanaan dapat dijalankan dengan baik. Pemerintah desa selalu identik dengan berbagai keluhan masyarakat akan pelayanan yang tidak maksimal. Kegagalan pembangunan disebabkan salah satunya karena kurangnya pengawasan dan peran kepala desa dalam menggerakkan partisipasi masyarakat dalam proses berlangsungnya pelaksanaan pembangunan desa (Laloma, n.d.)

Di Desa Bontomanai selama masa pemerintahan Kepala Desa dibantu oleh perangkat desa yang telah berlangsung satu periode (dalam Undang-undang Nomor 6 Tahun 2014 tentang Desa pasal 36 ayat 1 dan 2 menyebutkan bahwa Kepala Desa memegang jabatan selama 6 tahun terhitung sejak tanggal pelantikan dan Kepala Desa dapat menjabat paling banyak 3 kali masa jabatan secara berturut-turut atau tidak secara berturut-turut). Sampai penelitian ini dilakukan ada beberapa keluhan masyarakat mengenai pembangunan fisik yang kurang meningkat seperti pembangunan jalan lingkungan yang kurang memenuhi standar, serta sarana dan prasarana yang menunjang dalam penyelenggaraan pemerintahan desa yang masih kurang.

Kurangnya partisipasi masyarakat dalam hal perencanaan, pelaksanaan, hingga pengawasannya, sebagai salah satu penyebab kurang berhasilnya pembangunan di desa Bontomanai. Sehingga masyarakat tidak memiliki rasa tanggung jawab akan pembangunan di desanya. Hal ini disebabkan karena kurangnya pengetahuan masyarakat akan pentingnya pembangunan dan partisipasinya dalam pembangunan di desa. Hal tersebut menjadi kritik tersendiri bagi kepala desa dan perangkatnya yang dinilai belum melakukan upaya yang optimal dalam pembangunan dan pemberdayaan masyarakatnya.

Berdasarkan permasalahan diatas, jelas bahwa yang paling bertanggung jawab dalam setiap urusan pemerintahan di desa adalah kepala desa dibantu oleh perangkatnya. Sebagaimana yang diamanatkan oleh Undangundang Nomor 6 Tahun 2014 tentang desa bahwa sudah seharusnya seorang kepala desa melaksanakan tugasnya dengan penuh tanggung jawabnya terutama dalam pembangunan dan pemberdayaan masyarakat khususnya di Desa Bontomanai, sebagaimana telah dijelaskan bahwa keberhasilan suatu pembangunan sangat dipengaruhi oleh kinerja pemerintah desa.

\section{METODE}

Penelitian ini dilakukan di Desa Bontomanai Kecamatan Mangarabombang Kabupaten Takalar menggunakan pendekatan deskriptif kualitatif, dimana penelitian ini berusaha untuk menggambarkan pemecahan masalah yang ada berdasarkan data-data, jadi disamping juga menyajikan data, menganalisis dan menginterpretasi, ia juga bersifat komperatif dan korelasi (Narbuko, 2009). Data yang dimaksud bersumber dari data primer yang dikumpulkan melalui wawancara dan observasi dengan informan mengenai kinerja kepala desa dalam pelaksanaan pembangunan. Selain itu data sekunder yang bersumber dari literatur yang berhubungan dengan masalah penelitian seperti dokumen dari kantor desa Bontomanai.

Informan penelitian merupakan subjek yang memahami informasi dan objek penelitian ini yakni : kepala desa Bontomanai, Badan Permusawaratan Desa (BPD), Aparat Desa (Sekretaris dan Staf Desa) Tokoh Masyarakat, Tokoh Agama, Tokoh Pemuda dan Masyarakat Umum dan Masarakat Umum.

Analisis data dilakukan pada saat pengumpulan data berlangsung dan setelah selesai pengumpulan data dalam periode tertentu. Begitu juga pada saat wawancara 
langsung menganalisis jawaban dan jika dirasa kurang memuaskan maka pertanyaan dilanjutkan. Analisis data ini meliputi reduksi data, display serta verifikasi/menyimpulkan.

\section{HASIL DAN PEMBAHASAN}

Sebagaimana dijelaskan dalam Permendagri Nomor 114 tahun 2014 tentang Pedoman Pembangunan Desa yang menyatakan bahwa pembangunan desa dilaksanakan oleh pemerintah desa dengan melibatkan seluruh masyarakatnya dengan semangat gotong royong. Adapun hasil kerja pemerintah Desa dapat dilihat dari indikator kinerja yakni: kuantitas kerja (quantity of work),kualitas kerja (quality of work), pengetahuan kerja (job knowledge), kreativitas (creativiness), kerjasama (cooperation) dan kualitas pribadi (personal qualities) (Bernardin, H.J. \& Russel, 1993).

\section{Kuantitas Kerja (quantity of work)}

Kuantitas pekerjaan adalah indikator yang dapat menggambarkan jumlah kerja yang dilakukan oleh pemerintah desa dalam jangka waktu tertentu, dalam hal ini dapat diukur melalui jumlah pembangunan yang terealisasi sebagai berikut:

Tabel 1 Realisasi Pembangunan Tahun 2018

\begin{tabular}{|l|l|c|l|}
\hline No & \multicolumn{1}{|c|}{ Kegiatan } & \multicolumn{1}{|c|}{ Biaya } & $\begin{array}{l}\text { Sumber } \\
\text { Dana }\end{array}$ \\
\hline 1 & $\begin{array}{l}\text { Pembangunan } \\
\text { Jalan Paving Block } \\
\text { Dusun } \\
\text { Bontomanai }\end{array}$ & $92,833,000$ & $\begin{array}{l}\text { Dana } \\
\text { Desa }\end{array}$ \\
\hline 2 & $\begin{array}{l}\text { Pembangunan } \\
\text { Jalan Paving Block } \\
\text { Dusun Balang }\end{array}$ & $\begin{array}{l}27,562,000 \\
\text { Pembangunan } \\
\text { Jalan Paving Block } \\
\text { Dusun Balang }\end{array}$ & $\begin{array}{l}\text { Dana } \\
\text { Desa }\end{array}$ \\
\hline 4 & $\begin{array}{l}\text { Perintisan Jalan } \\
\text { Tani Dusun Balang }\end{array}$ & $169,381,000$ & $\begin{array}{l}\text { Dana } \\
\text { Desa } \\
\text { Desa }\end{array}$ \\
\hline
\end{tabular}

\begin{tabular}{|l|l|l|l|}
\hline 5 & $\begin{array}{l}\text { Pembangunan } \\
\text { Posyandu 1 Unit } \\
\text { Dusun Balang }\end{array}$ & $25,000,000$ & $\begin{array}{l}\text { Dana } \\
\text { Desa }\end{array}$ \\
\hline 6 & $\begin{array}{l}\text { Pembangunan } \\
\text { MCK 4 unit }\end{array}$ & $70,000,000$ & $\begin{array}{l}\text { Dana } \\
\text { Desa }\end{array}$ \\
\hline 7 & $\begin{array}{l}\text { Pengadaan Air } \\
\text { Bersih Berskala } \\
\text { Desa (PAMSIMAS) }\end{array}$ & $40,000,000$ & $\begin{array}{l}\text { Dana } \\
\text { Desa }\end{array}$ \\
\hline & Jumlah & $438,748,000$ & \\
\hline
\end{tabular}

Sumber: Hasil olahan dokumen kantor desa

Pendapatan yang diperoleh Desa Bontomanai untuk tahun 2018 bersumber dari :1) Dana Desa (DD) Rp. 1,012,717,000,2) Bagi Hasil Pajak dan Retribusi (BHPR) Rp. 58,540,500,- 3) Alokasi Dana Desa (ADD) Rp. $899,170,100,-$ sehingga total dana yang dikelola desa Bontomanai tahun 2018 adalah sebesar Rp. 1,970,427,600,-. Dana Desa (DD) diperuntukkan bidang pembangunan dan pemberdayaan masyarakat desa, sedangkan Alokasi Dana Desa (ADD) diperuntukakan bidang pemerintahan dan pembinaan masyarakat desa. Tahun 2018 peraturan Bupati Takalar membagi persentasi penggunaan Dana Desa yakni 40 \% digunakan untuk kegiatan pembangunan desa(fisik) dan $60 \%$ digunakan untuk kegiatan pemberdayaan masyarakat desa.

Tabel 2 Kegiatan Pemberdayaan Masyarakat Tahun 2018

\begin{tabular}{|l|l|l|l|}
\hline No & \multicolumn{1}{|c|}{ Kegiatan } & \multicolumn{1}{|c|}{ Biaya } & $\begin{array}{l}\text { Sumber } \\
\text { Dana }\end{array}$ \\
\hline 1 & $\begin{array}{l}\text { Pengadaan Bibit } \\
\text { Sapi 16 Ekor }\end{array}$ & $101,400,000$ & $\begin{array}{l}\text { Dana } \\
\text { Desa }\end{array}$ \\
\hline 2 & $\begin{array}{l}\text { Pengadaan Hand } \\
\text { Traktor 3 Unit }\end{array}$ & $90,000,000$ & $\begin{array}{l}\text { Dana } \\
\text { Desa }\end{array}$ \\
\hline 3 & $\begin{array}{l}\text { Pengadaan } \\
\text { Handsprayer 10 } \\
\text { Unit }\end{array}$ & $25,000,000$ & $\begin{array}{l}\text { Dana } \\
\text { Desa }\end{array}$ \\
\hline 4 & $\begin{array}{l}\text { Pengadaan Alat } \\
\text { Komunikasi HT 10 } \\
\text { Unit }\end{array}$ & $15,000,000$ & $\begin{array}{l}\text { Dana } \\
\text { Desa }\end{array}$ \\
\hline 5 & $\begin{array}{l}\text { Pengadaan Mesin } \\
\text { Pompa Air 10 Unit }\end{array}$ & $80,000,000$ & $\begin{array}{l}\text { Dana } \\
\text { Desa }\end{array}$ \\
\hline
\end{tabular}




\begin{tabular}{|c|c|c|c|}
\hline 6 & $\begin{array}{l}\text { Pengadaan Mesin } \\
\text { Pemotong Rumput } \\
10 \text { Unit }\end{array}$ & $20,000,000$ & $\begin{array}{l}\text { Dana } \\
\text { Desa }\end{array}$ \\
\hline 7 & $\begin{array}{l}\text { Pengadaan Mesin } \\
\text { Penggiling Tepung } \\
2 \text { Unit }\end{array}$ & $7,000,000$ & $\begin{array}{l}\text { Dana } \\
\text { Desa }\end{array}$ \\
\hline 8 & $\begin{array}{l}\text { Pengadaan Motor } \\
\text { Pengangkut } \\
\text { Sampah/Viar }\end{array}$ & $25,000,000$ & $\begin{array}{l}\text { Dana } \\
\text { Desa }\end{array}$ \\
\hline 9 & $\begin{array}{l}\text { Pengadaan Mesin } \\
\text { Kompressor } 2 \text { Unit }\end{array}$ & $7,000,000$ & $\begin{array}{l}\text { Dana } \\
\text { Desa }\end{array}$ \\
\hline 10 & $\begin{array}{l}\text { Pelatihan dan } \\
\text { Praktek bagi } \\
\text { Kelompok Tani }\end{array}$ & $6,000,000$ & $\begin{array}{l}\text { Dana } \\
\text { Desa }\end{array}$ \\
\hline 11 & $\begin{array}{l}\text { Pelatihan Pengurus } \\
\text { BUMDes }\end{array}$ & $10,000,000$ & $\begin{array}{l}\text { Dana } \\
\text { Desa }\end{array}$ \\
\hline 12 & $\begin{array}{l}\text { Sosialisasi tentang } \\
\text { Narkoba }\end{array}$ & $10,000,000$ & $\begin{array}{l}\text { Dana } \\
\text { Desa }\end{array}$ \\
\hline 13 & $\begin{array}{l}\text { Pelatihan } \\
\text { Teknologi Tepat } \\
\text { Guna }\end{array}$ & $10,000,000$ & $\begin{array}{l}\text { Dana } \\
\text { Desa }\end{array}$ \\
\hline 14 & $\begin{array}{l}\text { Insentif Kader } \\
\text { Kebersihan }\end{array}$ & $10,800,000$ & $\begin{array}{l}\text { Dana } \\
\text { Desa }\end{array}$ \\
\hline 15 & $\begin{array}{l}\text { Insentif Kader } \\
\text { keamanan }\end{array}$ & $10,800,000$ & $\begin{array}{l}\text { Dana } \\
\text { Desa }\end{array}$ \\
\hline 16 & $\begin{array}{l}\text { Insentif Kader } \\
\text { Kesehatan }\end{array}$ & $10,800,000$ & $\begin{array}{l}\text { Dana } \\
\text { Desa }\end{array}$ \\
\hline 17 & $\begin{array}{l}\text { Insentif Kader } \\
\text { Posyandu }\end{array}$ & $18,000,000$ & $\begin{array}{l}\text { Dana } \\
\text { Desa }\end{array}$ \\
\hline 18 & $\begin{array}{l}\text { Insentif Kader } \\
\text { Teknik }\end{array}$ & $14,400,000$ & $\begin{array}{l}\text { Dana } \\
\text { Desa }\end{array}$ \\
\hline \multirow[t]{2}{*}{19} & $\begin{array}{l}\text { Penertaan Modal } \\
\text { Desa untuk } \\
\text { BUmDes }\end{array}$ & $102,769,000$ & $\begin{array}{l}\text { Dana } \\
\text { Desa }\end{array}$ \\
\hline & Jumlah & $573,969,000$ & \\
\hline
\end{tabular}

Sumber: Hasil olahan dokumen kantor desa

Pada Tabel 1 dan 2 menunjukkan bahwa jumlah kegiatan yang penganggarannya bersumber dari Dana Desa telah terealisasi sesuai dengan Peraturan Bupati Takalar Nomor 43 Tahun 2018 Tentang Tata Cara Pembagian dan Penetapan Besaran dan Prioritas Dana Desa Setiap Desa Kabupaten Takalar, dimana bidang pembangunan desa sebesar Rp. 438.7148.000,- atau sebesar 40\% dari pagu Dana Desa Bontomanai Tahun 2018 serta bidang Pemberdayaan Masarakat adalah sebesar 573.969.000,- atau sebesar 60\% dari pagu.
Pembagian ini tidak sama pada tahun 2016 dan 2017 yakni 70\% diprioritas kan untuk pembangunan dan 30\% dari pagu diperuntukkan bidang pemberdayaan masyarakat. Perubahan komposisi tersebut di tahun 2018 sejalan dengan Permendes Nomor 19 Tahun 2017 Tentang Prioritas Penggunaan Dana Desa Tahun 2018 yang berfokus untuk membiayai program atau kegiatan pemberdayaan masyarakat. Hal ini sejalan pula dengan tujuan dana desa yakni untuk pembangunan dan pemberdayaan masyarakat desa. Oleh karena itu meskipun tujuan dana desa yang bersumber dari Anggaran Pendapatan dan Belanja Negara (APBN) memiliki prioritas pembangunan dan pemberdayaan masyarakat, namun tidak berarti pembangunan fisik saja yang diutamakan namun juga pemberdayaan masyarakat sehingga terwujud kemandirian desa serta desa terbebas dari belenggu kemiskinan dan dapat memenuhi kebutuhannya secara mandiri.

Dari hasil penelitian dilapangan bahwa meskipun anggaran untuk pemberdayaan masyarakat lebih besar, namun kegiatannya lebih banyak pada pengadaan alat, padahal seharusnya disamping pengadaan alat juga harus diberikan pelatihan bagaimana menggunakan alat tersebut dan manajemen usaha sehingga dapat meningkatkan taraf hidup masyarakat.

Sedangkan dalam kegiatan pembangunan fisik yang bertujuan pada peningkatan ekonomi dan pemberdayaan masyarakat juga belum maksimal. Hasil penelitian menunjukkan bahwa untuk pekerjaan fisik seharusnya dilaksanakan dengan pola swakelola sehingga dapat memberdayakan masyarakat lokal desa, namun beberapa kegiatan dikerjakan oleh rekanan yang ditunjuk oleh kepala desa.

Pola swakelola sebenarnya ditunjang pula oleh regulasi pemerintah melalui program Padat Karya Tunai Desa (PKTD) yang dikeluarkan berdasarkan Keputusan Bersama (SKB) 4 Menteri yakni Menteri PPN/Bappenas, Menteri Keuangan, Menteri 
Dalam Negeri, dan Menteri Desa Pembangunan Daerah Tertinggal dan Transmigrasi pada 18 Desember 2017 lalu memandatkan, bahwa Dana Desa digunakan untuk Padat Karya Tunai di Desa.

PKTD merupakan kegiatan pemberdayaan masyarakat desa, khususnya yang miskin dan marginal yang bersifat produktif, dengan mengutamakan pemanfaatan sumber daya, tenaga kerja, dan teknologi lokal untuk memberikan tambahan upah/pendapatan, meningkatkan daya beli, mengurangi kemiskinan, dan sekaligus mendukung penurunan angka stunting.

Dari uraian tersebut di atas menunjukkan bahwa kuantitas kerja pemerintah desa dalam pembangunan masyarakat cukup terpenuhi dalam segi jumlah karena sudah sesuai dengan regulasi yang ada, namun dari sisi pemenuhan kebutuhan masyarakat belum optimal.

\section{Kualitas Kerja (quality of work)}

Indikator penentu dalam menilai kualitas kerja seseorang adalah melalui kinerjanya. Banyak hal yang dapat mempengaruhi kualitas kerja baik internal maupun eksternal. Dalam hal internal berasal dari pribadi masing-masing pegawai seperti kemampuan dan pengalaman. Adapun eksternal yaitu penunjang dalam pelaksanaan seperti sarana dan prasarana atau target yang telah ditetapkan.

Hasil penelitian menunjukkan bahwa kualitas kerja Pemerintah Desa dalam pelaksanaan pembangunan masyarakatnya masih perlu ditingkatkan. Hal ini sejalan dengan data yang ada dilapangan bahwa disamping keterbatasan sumberdaya manusia baik dari segi tingkat pendidikan maupun keterampilan yang diperoleh dari pelatihanpelatihan sesuai bidang kerja perangkat desa masih minim.

Tabel 3 Data Aparat Desa Bontomanai Tahun 2018

\begin{tabular}{|c|c|c|l|}
\hline \multicolumn{2}{|c|}{ Profil Kepala Desa + Perangkat Desa } & \multirow{2}{*}{ Pelatihan yang pernah di ikuti } \\
\hline Jabatan & $\begin{array}{c}\text { Tingkat } \\
\text { Pendidikan }\end{array}$ & $\begin{array}{c}\text { Masa Kerja (TMT } \\
\text { Kerja) }\end{array}$ & \\
\hline Kepala Desa & S1 & 12 thn & $\begin{array}{l}\text { Embung Desa, Ketahanan Pangan, Siskeudes, } \\
\text { Perpajakan, Kampung KB, Kesling }\end{array}$ \\
\hline Sekretaris Desa & S1 & 30 thn & $\begin{array}{l}\text { Embung Desa, Ketahanan Pangan, Siskeudes, } \\
\text { Perpajakan, Kampung KB, Kesling }\end{array}$ \\
\hline Kaur Umum & SMA & 12 thn & \\
\hline Kasi Pemerintahan & SMA & 10 thn & $\begin{array}{l}\text { Siskeudes, peningkatan kapasitas aparat } \\
\text { desa }\end{array}$ \\
\hline Kaur Keuangan & SMA & 1 thn & \\
\hline Kasi Pemberdayaan Masy & SMA & 3 thn & \\
\hline Kasi Pembangunan & SMA & 12 thn & $\begin{array}{l}\text { Peningkatan Kapasitas aparat desa, } \\
\text { siskeudes, perpajakan }\end{array}$ \\
\hline Staf & SMA & 10 thn & $\begin{array}{l}\text { Peningkatan Kapasitas aparat desa, } \\
\text { siskeudes, perpajakan }\end{array}$ \\
\hline KADUS BONTOMANAI & SD & 25 thn & Penyuluhan Pertanian dan Kesehatan \\
\hline KADUS BONTO BILA & SMA & 3 thn & Penyuluhan Pertanian dan Kesehatan \\
\hline KADUS BONTO PA'JA & SMA & 2 thn & Penyuluhan Pertanian dan Kesehatan \\
\hline KADUS BALANG & SMA & 12 thn & Penyuluhan Pertanian dan Kesehatan \\
\hline KADUS LAKATONG PULAU & SMA & 15 thn & Penyuluhan Pertanian dan Kesehatan \\
\hline KADUS MATTEKE & SMP & 15 thn & Penyuluhan Pertanian dan Kesehatan \\
\hline
\end{tabular}

Sumber : Dokumen Kantor Desa 2018

Tabel 3 menunjukkan bahwa tingkat pendidikan perangkat desa yang masih rendah. Dari total 14 orang, yang berpendidikan S1 hanya 2 orang $(14,4 \%)$, SMA 10 orang $(71,4 \%)$, SMP 1 orang $(7,1 \%)$, SD 1 orang $(7,1 \%)$ sehingga perangkat desa mayoritas berpendidikan SMA. Padahal di level kepala desa sebaiknya tingkat pendidikan adalah S1 karena menyangkut dengan perencanaan yang berakibat pada keberhasilan pembangunan itu sendiri. Disamping itu minimnya kapasitas yang dimilki karena hampir tidak pernah diikutkan pada pelatihan yang sesuai dengan bidang kerja masing-masing. Begitu pula kepala desa dan sekretaris desa yang seharusnya lebih banyak lagi mengikuti peningkatan kapasitas baik dari segi tata kelola pemerintahan, kepemimpinan dan kelembagaan. Saat ini aparat desa adalah sebagai Human Capital sesuai dengan manajemen modern yang berpandangan bahwa manusia bukan lagi sekedar sebagi sumber tetapi juga sebagai penggerak sehingga dibutuhkan kapasitas yang memadai.

Kualitas kerja pemerintah desa Bontomanai berdasarkan observasi dan wawancara yang dilakukan pada penelitian ini menunjukkan bahwa sudah cukup baik namun masih harus ditingkatkan.

\section{Pengetahuan Kerja (Job Knowledge)}

Pengetahuan kerja bagi pemerintah desa merupakan hal yang harus dipahami 
untuk mendapatkan hasil yang baik dan optimal. Pengetahuan kerja seseorang dapat dipengaruhi oleh latar belakang pendidikan serta pengalaman yang dimiliki. Selain itu haruslah sejalan baik dari pengetahuan tentang perencanaan maupun dalam proses implementasinya dilapangan. Perencanaan pembangunan menjadi dasar bagi pemerintah desa untuk menciptakan program-program unggulan guna memajukan desanya.

Salah satu elemen yang mendasar dalam penyelenggaraan pembangunan desa adalah ketersediaan Rencana Pembangunan Jangka Menengah Desa (RPJMDes) dan Rencana Kerja Pemerintah Desa (RKPDes). Kedua dokumen ini merupakan arah kebijakan pembangunan dalam satu periode kepemimpinan kepala desa. Sehingga kualitas RPJMDes dan RKPDes menjadi hal yang penting pula dalam proses penyusunannya, kualitas dokumen maupun kesesuaian dengan regulasi. Hal penting lain adalah pengkajian keadaan desa yang wajib dilakukan dalam penyusunan perencanaan.

Hasil penelitian menunjukkan bahwa pengetahuan kerja pemerintah desa Bontomanai dalam pelaksanaan pembangunan belum memuaskan. Hal ini disebabkan karena kemampuan pengetahuan yang masih terbatas sebagai akibat tingkat pendidikan yang masih standar serta kurangnya pelatihan dan bimbingan yang sifatnya teknis menyangkut bidang kerja masing-masing aparat (lihat tabel 3).

\section{Kreativitas (Creativiness)}

Kreativitas biasanya merupakan pengembangan atas pemecahan masalah dan menjadi solusi dari permasalahan atau pekerjaan. Penyampaian ide atau gagasan biasanya terjadi didalam forum diskusi atau rapat, namun tidak menutup kemungkinan gagasan atau ide tersebut muncul saat bekerja.

Hasil penelitian terkait hal ini menunjukkan bahwa sebagian besar kreativitas dari pemerintah desa Bontomanai dalam pelaksanaan pembangunan masih standar. Ide-ide yang disampaikan umumnya masih terkait dengan pembangunan desa yang berbentuk fisik seperti perbaikan jalan tani, jalan paving, serta pembangunan posyandu (tabel 1). Pemerintah desa belum bisa mengoptimalkan potensi desanya dalam meningkatkan pendapatan desa untuk membiayai pembangunan yang hanya bersumber dari ADD dan DD yang serba dibatasi dengan regulasi sehingga merupakan kendala dalam pelaksanaan program pembangunan.

\section{Kerjasama (Coorporation)}

Kerja sama biasanya dilakukan atas dasar tujuan yang sama, yaitu tujuan yang hendak dicapai. Dalam suatu organisasi sangat diperlukan adanya suatu kerja sama kelompok (team work), karena semua penggerak suatu organisasi adalah manusia, bukan mesin, komputer atau yang lainnya (Setyanti, 2012). Kerjasama dalam organisasi atau instansi berarti pegawai saling membantu dalam hal pekerjaan untuk mencapai tujuan organisasi.

Kerjasama antar pemerintah desa dalam pelaksanaan pembangunan bermanfaat guna menumbuhkan semangat dan mempermudah jalannya kegiatan agar setiap program pembangunan dapat selesai tepat waktu. Dalam pelaksanaa pembangunan desa Bontomanai bekerjasama dengan Badan Permusyawaratan Desa (BPD), instansi terkait, dan semua elemen masyarakat. Begitu juga kerjasama yang dilakukan dengan pihakpihak terkait mulai tahap perencanaan sampai tahap pelaksanaan program pembangunan.

Penelitian ini menunjukkan bahwa pemerintah desa mampu menjalin kerjasama baik antar pemerintah desa sendiri maupun dengan BPD sebagai pengawas dalam pelaksanaan pembangunan serta elemenelemen tertentu untuk bekerjasama dalam mencapai tujuan pembangunan.

\section{Kualitas Pribadi (personal qualities)}

Kualitas pribadi menyangkut kepribadian, kepeimpinan, keramah tamahan, dan integritas pribadi masing-masing individu. Kualitas pribadi yang dimaksudkan 
adalah mengenai kemauan pemerintah desa untuk mengerjakan pekerjaannya dan keramahan dalam melakukan pelayanan kepada masyarakat.

Hasil penelitian menunjukkan bahwa kualitas pribadi pemerintah desa cukup baik, dimana pola kepemimpinan yang diterapkan kepala desa cenderung demokratis dan tegas dibeberapa kondisi serta kepala desa berbaur dengan aparat desa dan masyarakat sehingga tidak ada sekat diantara pemimpin dengan bawahan bahkan dengan masyarakatnya. Sebagian besar informan juga mengungkapkan bahwa kepala desa selalu berupaya untuk mensejahterakan masyarakat.

Aparat desa sendiri cukup ramah dengan masyarakat terutama dalam hal pelayanan, tanggap dalam bekerja meskipun masih ada aparat desa yang tidak bertanggung jawab terhadap amanah yang diemban. Kemauan aparat desa untuk bekerja cukup tinggi, dimana mereka saling memberikan saran serta masukan juga motivasi satu sama lain. Hal ini menggambarkan bahwa pemerintah desa bersama dengan masyarakat bekerjasama untuk mengerjakan program pembangunan masyarakat desanya.

\section{SIMPULAN DAN SARAN}

\section{Simpulan}

Berdasarkan hasil penelitian yang telah dilakukan mengenai kinerja pemerintah desa dalam rangka pelaksanaan pembangunan masyarakat di desa Bontomanai Kecamatan Mangarabombang Kabupaten Takalar dengan melihat bagimana kuantitas kerja, kualitas kerja, pengetahuan kerja, kerjasama, kreativitas dan kualitas pribadi pemerintah desa sudah cukup baik dan masih perlu ditingkatkan. Adapun indikator yang belum terpenuhi yaitu pengetahuan kerja dan kreativitas pemerintah desa yang masih kurang dalam pelaksanaan kegiatan pembangunan.

Adapun kendala dalam pelaksanaan kegiatan pembangunan desa seringkali disebabkan oleh beberapa faktor yaitu iklim atau keterlambatan bahan material sehingga beberapa program tidak sesuai dengan waktu yang telah ditentukan begitu juga dengan anggaran yang terbatas. Dalam hal partisipasi masyarakat masih perlu ditingkatkan dalam pelaksanaan kegiatan pembangunan

\section{Saran}

Berdasarkan kesmpulan diatas, maka beberapa saran kepada pemerintah desa seperti : harus lebih memahami fungsi dan tugas pokok masing-masing, harus lebih bersinergi dengan BPD dalam menjalankan tugas memberdayakan masyarakat, harus menumbuhkan kesadaran masyaraat untuk berkontribusi dalam setiap pelaksanaan pembangunan, harus mampu menganalisis potensi-potensi desa serta kendala dalam pembangunan, harus mampu menciptakan ide-ide atau gagasan bagi program pembangunan yang inovatif, mampu mengadakan forum-forum diskusi terkait pembangunan untuk membuka wawasan serta mampu mengoptimalkan potensi desa sehingga dapat menambah pendapatan desa.

\section{REFERENSI}

Bernardin, H.J. \& Russel, J. E. . (1993). No Title Human Resource Management an experiental approach. Singapore: Mc Graw-Hill, Inc. Davis, Keith ...

Laloma, A. (n.d.). DESA TOLOK SATU KECAMATAN TOMPASO MAYA ONIBALA BURHANUDDIN KIYAI.

Narbuko, K. (2009). No Title Metodologi Penelitian. Jakarta: Bumi Aksara.

Nurdin, N. (n.d.). Network Model of Local Development Planning: Case of Local Development Planning Forum in Bone Regency 目.

Setyanti, S. W. (2012). Membangun Kerjasama Tim (Kelompok). 4(3), 59-65.

Soewignjo. (1986). No Title Administrasi Pembangunan Desa dan Sumber-sumber Pendapatan Desa. Jakarta: Ghalia Indonesia. 